\title{
Aeromonas hydrophila AHL 0905-2 and Streptococcus agalactiae N14G as Combined Vaccine Candidates for Nile Tilapia
}

\author{
Nunak Nafiqoh ${ }^{1}$, Hessy Novita ${ }^{1 *}$, Desy Sugiani ${ }^{1}$, Lila Gardenia ${ }^{1}$, Taukhid $^{1}$, Arynta Widyaningrum $^{2}$, Dine Resti Susanti ${ }^{2}$ \\ ${ }^{1}$ Research Institute for Fresh Water Aquaculture and Fisheries Extension (RIFAFE), Bogor, Indonesia \\ ${ }^{2} P$ T. Caprifarmindo Laboratories, Bandung, Indonesia
}

ARTICLE INFO

Article history:

Received September 25, 2021

Received in revised form November 15, 2021

Accepted December 2, 2021

\section{KEYWORDS:}

co-infection,

PCR,

Aeromonas hydrophila,

Streptococcus agalactiae,

Oreochromis niloticus

\begin{abstract}
In Indonesia, the Nile tilapia (Oreochromis niloticus) is the most widely farmed and available fish for consumption. Production loss due to bacterial infection by Aeromonas hydrophila and Streptococcus agalactiae is the main problem in tilapia cultivation. This study aimed to determine the occurrence of concurrent infection of Aeromonas hydrophila AHL 0905-2 and Streptococcus agalactiae N14G in Nile tilapia based on biochemical and molecular characteristics. From the results of biochemical assay and sequence analysis of the 16S rRNA fragment, Aeromonas hydrophila and Streptococcus agalactiae were confirmed. Genes for aerolysin (417 bp), nuclease (504 bp), lipase (155 bp), and serine protease (211 bp) were found in Aeromonas hydrophila AHL 0905-2, while Streptococcus agalactiae N14G was determined as a 1b serotype group that had genes for CPS L (688 bp), CPSG (621 bp), and CPS J (272 bp). The confirmation in tilapia of Aeromonas hydrophila and Streptococcus agalactiae by PCR and sequencing is important for enabling the detection of these organisms and also for the development of a combined vaccine to tackle co-infection.
\end{abstract}

\section{Introduction}

Indonesia is the second-largest producer of Nile tilapia (Oreochromis niloticus) in the world (after China) (FAO 2017). The species has high economic value and is suitable for aquaculture because of its tolerance to handling, fast growth, tolerance of a wide range of environmental conditions, such as $\mathrm{pH}$, temperature and salinity, and its high marketability (Hassanien et al. 2004). However, tilapia is susceptible to many diseases caused by single or multiple microbial pathogen infections that can cause high mortality rates in cultivation (Dong et al. 2015). Motile Aeromonas Septicemia (MAS) caused by A. hydrophila and streptococcosis caused by $S$. agalactiae are bacterial diseases threatening the survival of these fish through co-infection.

Streptococcus agalactiae or Lancefield Group B Streptococcus (GBS) is a Gram-positive bacterium commonly causing streptococcosis in tilapia. Worldwide, this bacterial pathogen is regarded as the most serious disease for tilapia, and in the last decade has become the major infection in these fish

\footnotetext{
* Corresponding Author

E-mail Address: hestahamdani@gmail.com
}

(Garcia et al. 2008; Al Harbi 2016). The bacterium can also infect other fresh and seawater fish (Garcia et al. 2008; Bowater et al. 2012; Al Harbi 2016). The main entry point of of $S$. agalactiae infection is the gastrointestinal epithelium, leading to fibrinous pericarditis and peritonitis, with hemorrhages around the brain, retrobulbar regions, and intestines resulting in severe consequences (Iregui et al. 2015).

Aeromonas hydrophila is known worldwide as causing septicemia disease that affects numerous species of freshwater and marine fish. It is also considered as the most significant disease affecting fish farming (Aoki 1999). Congestion and hemorrhage of the abdominal wall and the base of the fins, together with scale erosion of various parts of the body, are the marked clinical signs observed (Asaad 2008). The infection caused by this bacteria is also recorded as causing severe congestion of internal organs with the accumulation of ascetic fluid in the abdominal cavity, swelling of the kidney and spleen, features on the surface of the body and gills, ulcers, abscesses, exopthalmias, andbloated stomach(Austin and Austin 1993). In Indonesia, MAS is an economic hazard causing severe losses in cultured freshwater fish species, including 0 . niloticus, common carp, and catfish. However, increasing water changing, 
elevation of aquatic column highs, and cessation of feeding can help in reducing the deleterious effects of outbreaks, although not solving the problem completely.

Co-infection occurs when hosts are infected by two or more different pathogens, either simultaneously or as secondary infections, so that two or more infectious agents are active together in the same host (Kotob et al. 2016). In this study, Aeromonas hydrophila AHL 0905-2 and Streptococcus agalactiae N14G are characterized based on biochemical characteristics and hemolytic ability. Therefore, this study aims to determine the identification of concurrent infection of A. hydrophila AHL 0905-2 and S. agalactiae N14G in Nile tilapia through molecular PCR and sequencing methods.

\section{Materials and Methods}

\subsection{Koch's Postulates Test}

The A. hydrophila (AHL 0905-2) and S. agalactiae (N14G) bacterial isolates were obtained and analyzed using Koch's postulates (PK). An overnight culture of the isolates was prepared in a bacterial suspension (log-phase growth) through the following process: a single colony of each bacterial isolate was inoculated in $10 \mathrm{ml}$ of Tryptic Soy Broth (TSB) and Brain Heart Infusion Broth (BHIB) (for $A$. hydrophila and $S$. agalactiae) at $28^{\circ} \mathrm{C}$ for 24 and $48 \mathrm{~h}$, respectively. Afterwards, the bacterial suspension was adjusted to OD $600 \mathrm{~nm}$ at 0.55 to 0.60 for both isolates, respectively, before applying the PK process. A total of ten healthy fish (mean weight, $10 \mathrm{~cm} \pm 10 \mathrm{~g}$ ) were then each intraperitoneally injected with $1 \times 10^{6}$ $\mathrm{CFU} / \mathrm{ml}$ and $1 \times 10^{8} \mathrm{CFU} / \mathrm{ml}$ of $A$. hydrophila (AHL 0905-2) and S. agalactiae (N14G), respectively.

\subsection{Bacterial Isolation}

In this study, two media, namely Tryptic Soy Agar (TSA) and Brain Heart Infusion Agar (BHIA) (Oxoid Ltd, UK), were used in the culture of $A$. hydrophila and $S$. agalactiae infections, respectively. The targeted organs of diseased fishes were aseptically obtained by inserting a sterile loop into the target tissue and streaking them directly onto the different media. The plates were incubated at $28^{\circ} \mathrm{C}$ for 24 (TSA) and 48 (BHIA) hours, respectively.

\subsection{Biochemical Characteristics}

In this study, biochemical assays were also performed in order to identify culturable isolates of A. hydrophila AHL 0905-2 and S. agalactiae N14G. All isolates were subjected to primary tests, including hemolysis ability, Gram staining, oxidation/ fermentation (O-F), motility, oxidase, catalase, API $20 \mathrm{E}$, and API 20 Strep. The bacterial isolates were cultured at $28^{\circ} \mathrm{C}$ for 4 and 24 hours.

\subsection{DNA Extraction from Colony Bacterial Isolates}

The genomic DNA of pure bacterial isolates was extracted by the boiling method, as previously described by Arias et al. (2004), with modification. After bacterial isolates were cultured for 18-20 hours in agar media they were collected from 1 to 2 colonies by sterile loop. Afterwards, cell pellets were suspended in $500 \mu \mathrm{l}$ nuclease-free water and boiled for 10 mins, before being immediately cooled down in ice. After centrifuging at 1,200 rpm for 10 mins, supernatant containing DNA templates was obtained and used in the PCR assay.

\subsection{Specific PCR Assays}

\subsubsection{Detection of $A$. hydrophila AHL 0905-2}

PCR detection assays of A. hydrophila AHL 0905-2 were performed using DNA templates extracted from isolated bacterial colonies grown in the TSA medium (Oxoid Ltd, UK). Specific primers (Table 1) targeting virulence genes of $A$. hydrophila, as described by Nam and Joh (2007) with Novita et al. (2018), were also used in this study. The PCR mixtures contained $12.5 \mu$ master mix (GoTaq ${ }^{\circledR G r e e n, ~ P r o m e g a, ~ U S A), ~}$ $10 \mathrm{pmol}$ of each primer, and $2 \mu \mathrm{l}$ of DNA template in a final volume of $25 \mu \mathrm{l}$. Amplification was carried out in a thermocycler (MJ Research) through denaturation at $94^{\circ} \mathrm{C}$ for 2 mins accompanied by 30 cycles of amplification at $95^{\circ} \mathrm{C}$ for $1 \mathrm{~min}$. Afterwards, annealing at $55^{\circ} \mathrm{C}$ for $1 \mathrm{~min}$ was conducted, with ordinal and final extensions both carried out at $72^{\circ} \mathrm{C}$ for $1 \mathrm{~min}$. The genomic DNA of the isolate was further used as a template and with nuclease-free water for both positive and negative controls, respectively. Also, the amplified products of $A$. hydrophila were visualized by GelDoc, after being electrophoresed with $1.5 \%$ agarose gel in TAE $1 \mathrm{x}$ and stained with cybersafe (Promega).

\subsubsection{Detection of S. agalactiae N14G}

Investigation of $S$. agalactiae N14G infection was carried out using serotyping primers (Table 1) (modification of Imperi et al. 2010) with the bacteria being cultured in BHIA medium. PCR assay was performed in the same way as described for $A$. hydrophila detection. The thermocycling conditions applied were $95^{\circ} \mathrm{C}$ for 5 mins accompanied by 35 cycles at $94^{\circ} \mathrm{C}$ for $1 \mathrm{~min}$. Afterwards, annealing and extension were carried out at $50^{\circ} \mathrm{C}$ and $72^{\circ} \mathrm{C}$ for $1 \mathrm{~min}$ each, with final extension then conducted at $72^{\circ} \mathrm{C}$ for 
Table 1. Oligonucleotide primers used in PCR assays for A. hydrophila and S. agalactiae

\begin{tabular}{|c|c|c|c|}
\hline Gene & Primers & Sequence (5'--->3') & Band PCR (bp) \\
\hline \multicolumn{4}{|l|}{ A. hydrophila } \\
\hline \multirow[t]{2}{*}{$16 \mathrm{~S}$ rDNA } & 16S-rDNA-F & AGAGTTTGATCATGGCTCAG & 1,502 \\
\hline & 16S-rDNA-R & GGTTACCTTGTTACGACTT & \\
\hline \multirow{2}{*}{ Nuclease } & Nuc-F & CAGGATCTGAACCGCCTCTATCAGG & 504 \\
\hline & Nuc-R & GTCCCAAGCTTCGAACAGTTTACGC & \\
\hline \multirow[t]{2}{*}{ Aerolysin } & Aero-F & GAGCGAGAAGGTGACCACCAAGAAC & 417 \\
\hline & Aero- $R$ & ТTCСАGТСССАССАСТТСАСТТСАС & \\
\hline Serine & Ser-F & ACGGAGTGCGTTCTTCCTACTCCAG & 211 \\
\hline \multirow[t]{2}{*}{ Protease } & Ser-R & CCGTTCATCACACCGTTGTAGTCG & \\
\hline & Lip-F & GACССССТАССТGАACСТGАGСТАС & 155 \\
\hline Lipase & Lip-R & AGTGACCCAGGAAGTGCAC CTTGAG & \\
\hline \multicolumn{4}{|l|}{ S. agalactiae } \\
\hline \multirow[t]{2}{*}{ cps L } & cps L-F & CAATCCTAAGTATTTTCGGTTCATT & 688 \\
\hline & cps L-R & TAGGAACATGTTCATTAACATAGC & \\
\hline \multirow{2}{*}{ cps J } & cps J-F & GCAATTCTTAACAGAATATTCAGTTG & 621 \\
\hline & cps J-R & GCGTTTCTTTATCACATACTCTTG & \\
\hline \multirow[t]{2}{*}{ cps G } & cps G-F & ACATGAACAGCAGTTCAACCGT & 272 \\
\hline & cps G-R & ATGCTCTCCAАACTGTTCTTGT & \\
\hline
\end{tabular}

7 mins. The DNA template extracted from the isolate of $S$. agalactiae was also used with nuclease-free water for positive and negative controls, respectively. Finally, amplified products were electrophoresed and visualized using GelDoc.

\subsection{S rDNA Amplification and DNA Sequencing}

The two sets of universal primer targeting prokaryotic 16S rDNA used in this study (Table 2) included F/R (Nam and Joh et al. 2007) for isolates of Aeromonas spp. and S. agalactiae (Agal I F1 and Agal II R) (Yildirim 2002; Lusiastuti et al. 2013). The PCR mixtures contained $10 \mathrm{pMol}$ of each primer pair, $12.5 \mu \mathrm{l}$ master mix (GoTaq ${ }^{\circledR G}$ Green, Promega, USA), and $2 \mu \mathrm{l}$ of DNA template in a final volume of 25 $\mu \mathrm{l}$. Amplification was carried out in the MJ Research thermocycler through denaturation at $94^{\circ} \mathrm{C}$ for 2 mins accompanied by 30 and 25 cycles of amplification at $95^{\circ} \mathrm{C}$ for $1 \mathrm{~min}$. Afterwards, annealing at $55^{\circ} \mathrm{C}$ and $50^{\circ} \mathrm{C}$ for $1 \mathrm{~min}$ was carried out, with initial and final extension also conducted for both at $72^{\circ} \mathrm{C}$ for 1 min, with amplified products of $\sim 1.5 \mathrm{~kb}$ and $1.2 \mathrm{~kb}$, respectively. The unpurified DNA amplicons were submitted for DNA sequencing to $1^{\text {st }}$ BASE Pte Ltd, Singapore, with homology search being carried out using nucleotide BLAST from the GenBank database of the National Center for Biotechnology Information (NCBI). In this study, multiple sequence alignments of the 16S rRNA gene sequences of the bacterial isolates and their closed taxa were retrieved from GenBank using the Clustal W method. A phylogenetic tree was constructed through the use of the neighbor-joining method of MEGA version X software (Tamura et al. 2011).
Table 2. 16SrDNA of A. hydrophila and S. agalactiae

\begin{tabular}{ll}
\hline Primer pair & $\begin{array}{l}\text { thermocycler } \\
\text { condition }\end{array}$ \\
\hline A. hydrophila (16 Sr DNA): 1,502 Bp & $95^{\circ} \mathrm{C}$ for $5 \mathrm{~min}$ \\
(Nam and Joh et al. 2007) & $94^{\circ} \mathrm{C}$ for $1 \mathrm{~min}$ \\
16S-rDNA-F: AGAGTTTGATCATGGCTCAG & $55^{\circ} \mathrm{C}$ for $1 \mathrm{~min}$ \\
$72^{\circ} \mathrm{C}$ for $1 \mathrm{~min}$ \\
16S-rDNA-R: GGTTACCTTGTTACGACTT & $72^{\circ} \mathrm{C}$ for 7 min \\
& 30 cycles \\
\hline S. agalactiae (Agal I, II): 1,250 bp & $95^{\circ} \mathrm{C}$ for 5 min \\
(Yildirim 2002; Lusiastuti et al. 2013) & $94^{\circ} \mathrm{C}$ for 1 min \\
agal I- 5'-ATAAGAGTAATTAACACATGTT & $50^{\circ} \mathrm{C}$ for 1 min \\
AG-3' & \\
agal II-5'-ACTTCGGGTGTTACAAA C-3' & $72^{\circ} \mathrm{C}$ for 1 min \\
& $72^{\circ} \mathrm{C}$ for 7 min \\
& 35 cycles \\
\hline
\end{tabular}

\section{Results}

\subsection{Koch's Postulates Test}

The Koch's postulates of A. hydrophila AHL 09052 and S. agalactiae N14G bacteria, with the aim of conducted to verify abaility to couse disease of these bacteria in nile tilapia (see Figure 1). After 24 hours of bacterial infection, clinical symptoms occurred on the surface of the body, as the belly of the fish turned white and hemorrhagic extensions became evident on body surfaces, the base of the caudal fin, and the operculum. Changes in internal pathology, such as swelling of the liver and spleen and bleeding in stomach also tended to occur. The occurrence of these symptoms indicated the presence of $A$. hydrophila AHL 0905-2 infection. However, this bacteria was likely to be isolated from the kidney and liver. The symptoms of infection with 


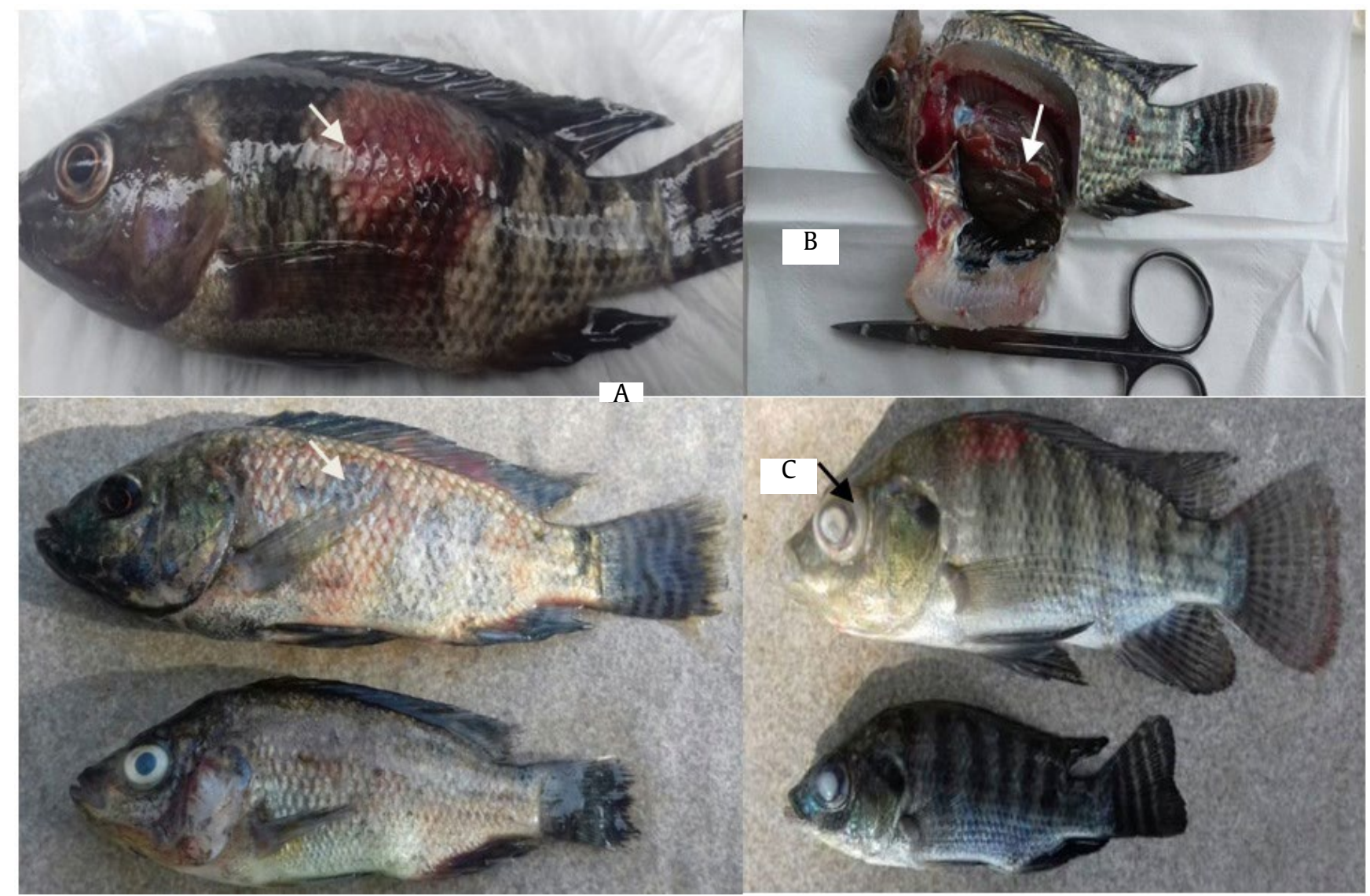

Figure 1. (A) Co-infection by A. hydrophila AHL 0905-2 and S. agalactiae N14G in tilapia after postulate assays, with hemorrhagic extensions on body surface leading to swelling of the liver, (B) spleen and bleeding in stomach, (C) necrotic gills, swollen gall bladder, hemorrhagic liver, protruding eyes, bloated stomach, bleeding in the eyes, hemorrhages of the gill and base of tail, black appearing on body surface

S. agalactiae N14G included disorientation, swimming in circles on the surface, protruding, bloating of the stomach, bleeding in the eye, hemorrhages of the gills and base of tail, body surfaces becoming black, and chaotic fast-swimming activity. Also, the internal organs exhibited damage to the kidneys, liver, spleen, and intestines. S. agalactiae N14G was isolated from the brain.

\subsection{Bacterial Isolation and Biochemical Characterization}

Re-isolation of A. hydrophila AHL 0905-2 and S. agalactiae $\mathrm{N} 14 \mathrm{G}$ after Koch's postulate assay in tilapia was carried out by re-culturing in TSA and BHIA for screening. The results obtained for characteristics and identification of these bacterial species by biochemical characterization are shown in Table 3. Based on biochemical characterization, A. hydrophila AHL 0905-2 and S. agalactiae $\mathrm{N} 14 \mathrm{G}$ were identified as Gram-negative and Gram-positive, respectively. Also, A. hydrophila AHL 0905-2 was positive for short rod, motility, and API $20 \mathrm{E}$ tests. The results for API $20 \mathrm{E}$ showed positive for esculin hydrolysis, Voges-Proskauer test, growth at $37^{\circ} \mathrm{C}$, galactosidase, arginine dihydrolase, arabinose, glucose, mannitol, hemolysis, $\mathrm{H}_{2} \mathrm{~S}$ production, indole, gelatin hydrolysis, aesculin hydrolysis, development of KCN, selisin, and sucrose. The biochemical characterization of $S$. agalactiae N14G was positive for coccus form, fermentative, esculin hydrolase, d-mannitol acid, and growth at $37^{\circ} \mathrm{C}$. The API 20 STREP test results further showed that $S$. agalactiae N14G was a non-hemolytic bacterium with the ability to hydrolyze sugars from sodium pyruvate, hippuric acid, arginine dihydrolase, ribose, sorbitol, lactose, trehalose, and amidon. The ability of this bacterium to hydrolyze sugar indicates its tendency to survive in the host's body by utilizing the nutrients present in the fish.

\subsection{PCR Assays of A. hydrophila AHL 0905-2 and $S$. agalactiae N14G}

Based on gene virulence and serotyping, confirmations of A. hydrophila AHL 0905-2 and S. agalactiae N14G by PCR were also conducted. Virulence factor gene detection of $A$. hydrophila AHL 0905-2 was carried out using specific primers, such as aerolysin (417 bp), nuclease (504 bp), lipase (155 bp), and serine protease (211 bp) (Figure 2). A. hydrophila AHL 09052 was positive with $16 \mathrm{~S}$ rDNA, as PCR bands resulted 
Table 3. Morphology and biochemical characterization A. hydrophila AHL 0905-2 and S. agalactiae N14G d: variable reaction, $(+)$ : positive, $(-)$ : negative, $\mathrm{F}$ : fermentative

\begin{tabular}{|c|c|c|c|}
\hline $\begin{array}{l}\text { Biochemical characterization } \\
\text { API } 20 \mathrm{E}\end{array}$ & $\begin{array}{l}\text { A. hydrophila AHL } \\
0905-2\end{array}$ & $\begin{array}{l}\text { Biochemical characterization } \\
\text { API } 20 \text { Strep }\end{array}$ & S. agalactiae $\mathrm{N} 14 \mathrm{G}$ \\
\hline Form & Short rod & Form & Coccus \\
\hline Motility & + & Motility & - \\
\hline Gram & - & Gram & + \\
\hline Esculin hydrolisys & + & oxicidase & - \\
\hline Voges-Proskauer & + & $\mathrm{O} / \mathrm{F}$ & $\mathrm{F}$ \\
\hline Growth at $37^{\circ} \mathrm{C}$ & + & catalase & - \\
\hline Diffusible brown pigment & - & Bile salt & - \\
\hline B-galactosidase & + & $\mathrm{NACl} 6.5 \%$ & - \\
\hline Arginine dihydrolase & + & Esculin hydrolase & + \\
\hline Arabinosa & + & D- Mannitol acid & + \\
\hline Glucose & + & Growth at $37^{\circ} \mathrm{C}$ & + \\
\hline Inositol & - & Hemolysis & - \\
\hline Manitol & + & Sodium piruvate & + \\
\hline Hemolysis & + & hipuric acid & + \\
\hline Lysine decarboxylase & $\mathrm{d}$ & Escullin ferric citrate & - \\
\hline Ornithine decarboxylase & - & $\begin{array}{l}\text { Pyroglutamic acid- } \beta- \\
\text { naphtylamide }\end{array}$ & - \\
\hline Simmons citrate & $\mathrm{d}$ & $\alpha$-Galactosidase & - \\
\hline $\mathrm{H}_{2} \mathrm{~S}$ production & + & $\beta$-Glucuronidase & - \\
\hline Urease & - & $\beta$-Galactosidase & - \\
\hline Indole & + & Alkaline Phosphatase & - \\
\hline Gelatine hydrolysis & + & L-Leucine- $\beta$-naphtylamide & - \\
\hline Aesculin hydrolysis & + & L-Arginin & + \\
\hline Growth in KCN & + & D-Ribose & + \\
\hline Selisin & + & L-arabinose & + \\
\hline Sorbitol & + & D-mannitol & - \\
\hline Sucrose & + & D-Sorbitol & + \\
\hline L-rhamnose & - & D-Lactose & + \\
\hline D-sucrose & + & D-trehalose & + \\
\hline D-melibiose & - & Inuline & - \\
\hline Amygdalin & + & D-Raffinose & - \\
\hline L-arabinose & - & Amidon & + \\
\hline Oxidase & - & Glycogen & - \\
\hline
\end{tabular}

d: variable reaction, (+): positive, (-): negative, F: Fermentative

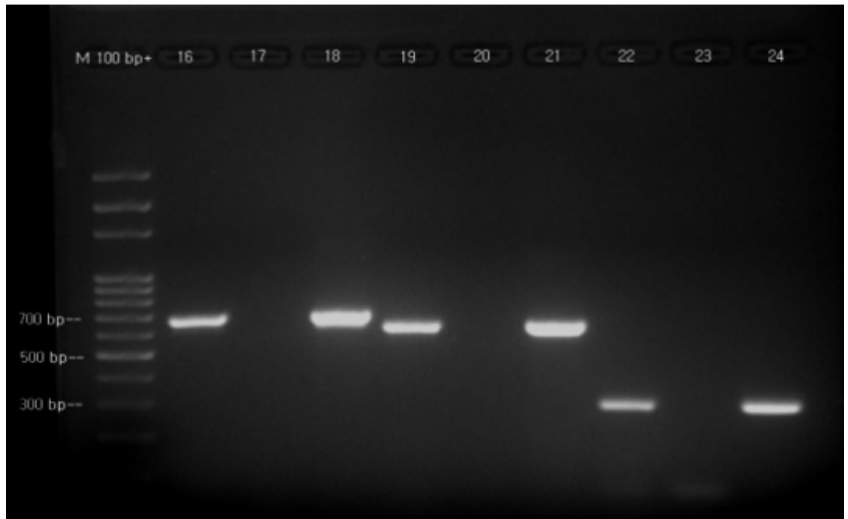

Figure 2. PCR assay with specific primer of $A$. hydrophila AHL 0905-2, M: Marker 100 bp, 1: A. hydrophila AHL 0905-2, 2: (-)ve control, 3: (+)ve control 16s rDNA (1,502 bp), 4: A. hydrophila AHL 0905-2, 5: (-)ve control, 6: (+)ve control nuclease (504 bp), 7: A. hydrophila AHL 0905-2, 8: (-)ve control, 9: (+)ve control aerolysin (417 bp), 10: A. hydrophila AHL 0905-2, 11: (-)ve control, 12: (+)ve control serine protease (211 bp), 13: A. hydrophila AHL 0905-2, 14: (-)ve control, 15: (+)ve control lipase (155 bp) of $1,502 \mathrm{bp}$. Also, the $16 \mathrm{~S}$ rDNA gene sequence was observed in almost all types of bacteria and used as a source of information for the microorganisms.

Three primer pairs were set up to discriminate the serotypes of $S$. agalactiae N14G with amplicon patterns through the use of PCR assay. The primer set was designed from $S$. agalactiae serotype group $1 \mathrm{~b}$ based on the standard amplicon patterns described previously by Table 1 . This primer created amplicons of CPS L (688 bp), CPS J (621 bp), and CPS G (272 bp) (Figure 3). The molecular serotyping of $S$. agalactiae N14G indicated that according to biochemical assay it was a non-hemolytic bacterium. Therefore, $S$. agalactiae N14G could be used in the development of a combined vaccine in tilapia.

\subsection{Sequence Results of $A$. hydrophila AHL 0905-2 and $S$. agalactiae N14G}

The genomic DNA of $A$. hydrophila AHL 0905-2 and S. agalactiae N14G isolated and extracted from the isolates was then used as a template for the 


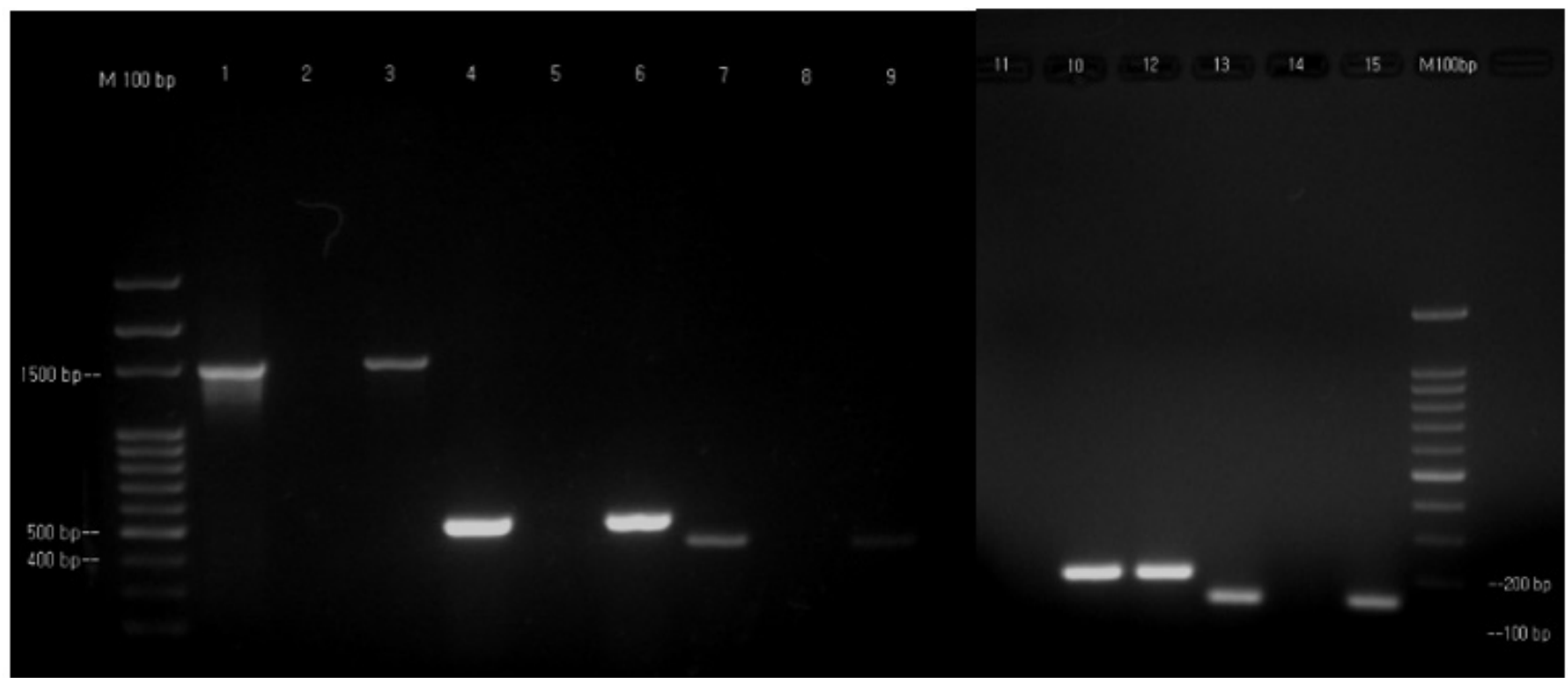

Figure 3. PCR assay of S. agalactiae based on serotyping in group 1b. M: Marker 100 bp; 16: S. agalactiae N14G; 17: (-)ve control; 18: (+)ve control CPS L (688 bp); 19: S. agalactiae N14G; 20: (-)ve control; 21: (+)ve control CPS J (621 bp); 22: S. agalactiae N14G; 23: (-)ve control; 24: (+)ve control CPS G (272 bp)

detection of $16 \mathrm{~S}$ rRNA and serotyping using the PCR method. This amplification process was expected to amplify the usual $16 \mathrm{~S}$ rRNA gene, which measured up to $1,500 \mathrm{bp}$ in length. The results of the amplification were obtained through electrophoresis with agarose and visualized with GelDoc to identify species of bacteria. Afterwards, amplification was carried out by the sequencing process in order to confirm $A$. hydrophila AHL 0905-2 and S. agalactiae N14G. The results of identification via BLAST are shown in Figure 4.

Based on the BLAST findings, the nucleotide sequences of $A$. hydrophila AHL 0905-2 showed $100 \%$ similarity with A. hydrophila strain F_28 (MG428737.1). Also, the virulence genes of this bacteria had 97.84\%, 99.48\%, 99.42\%, and 99.48\% similarities with A. hydrophila subsp. strains WCHAH045096 (CP028568.2), PB80AH1 (AY442276.1), AH-1 (AY841795.1), and AHLIP7 (AB237179.1) for nuclease, aerolysin, serine protease, and lipase, respectively. Profile nucleotide sequences used serotyping for molecular identification results, as S. agalactiae N14G obtained by homologous levels had $98.39 \%$, 98.64\%, 96.75\%, and 98.93\% similarities with Streptococcus agalactiae strains QMA0271 (CP029632.1), YZ1605 (CP026082.1), NCTC8187 (LT671984.1), and (MT626756.1) for CPS L, CPS G, and AGAL12, respectively.

Also, sequence alignment of $A$. hydrophila AHL 0905-2 and S. agalactiae N14G from the database Gene Bank was carried out using the MEGA X program. In order to obtain a phylogenetic tree, the NJ program on Clustal W software was used with a level of $1000 x$ bootstrap, with results as shown in Figure 4. The phylogenetic tree shows the relationships between both of these species based on the different molecular characteristics of $t$ strains within the same species.

Figure 4 confirms the relationship level of $A$. hydrophila AHL 0905-2 and S. agalactiae N14G. Therefore, the isolates already existing from the morphological and biochemical test results were shown to be A. hydrophila AHL 0905-2 and S. agalactiae $\mathrm{N} 14 \mathrm{G}$.

\section{Discussion}

Co-infection of A. hydrophila AHL 0905-2 and S. agalactiae N14G in tilapia often occurs and causes economic losses for fish farmers resulting from slow fish growth, longer maintenance time, high feed conversion, low stocking density, and higher mortality rates. Conventional characterization of these two bacteria by biochemical tests has often been inconsistent and weak in determining bacterial species discriminatively, with molecular detection proving to be more accurate. Also, it is known that, based on the surface of the polysaccharide antigen, $S$. agalactiae has several serotypes, namely Ia, Ib, II, III, IV, V, VI, VII, VIII, and IX, with some having protein antigens such as C, R, and X (Gravekamp et al. 1999; Imperi et al. 2010). Hitherto, in order to determine $S$. agalactiae, capsular molecular serotyping with sequencing provided an accurate method of typing 


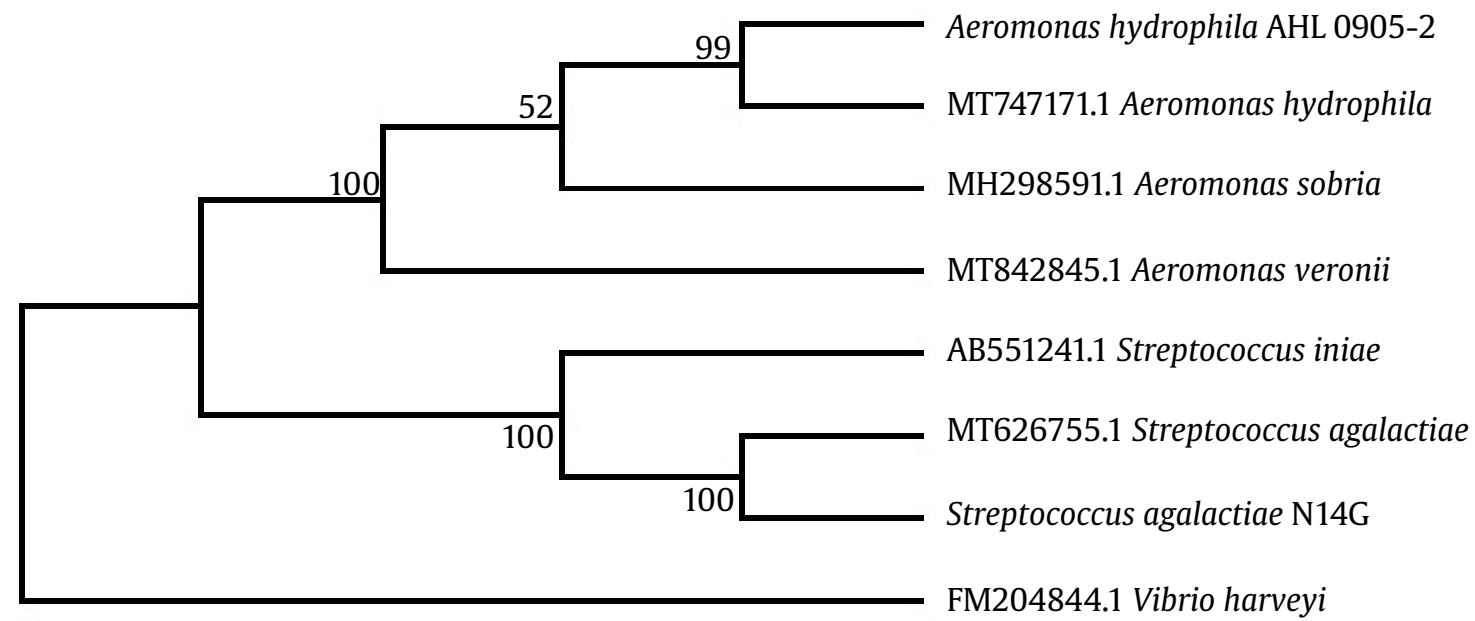

Figure 4. Philogeny tree with bootstrap 1000x of A. hydrophila AHL 0905-2 and S. agalactiae N14G using the MEGA X software with NJ program on Clustal W

(Jones et al. 2003; Carvalho et al. 2017; Kapatai et al. 2017). This was due to the fact that capsular serotypes were more important for vaccine formulation, and capsular polysaccharides (CPS), which are highly immunogenic, provide the best form of protection against infections (Eldar et al. 1995; Berkley et al. 2016). Also, the serotypes Ia and Ib of $S$. agalactiae are often discovered in aquatic animals.

Furthermore, with A. hydrophila AHL 0905-2 also having many strains, this bacteria is another pathogen causing disease. As reported by Dong et al. $(2015,2017)$, other pathogens causing diseases apart from co-infection by $A$. hydrophila and $S$. agalactiae are Iridovirus and TiLV, with symptoms and target organs mimicking the main internal and external clinical signs of naturally infected tilapia. However, the genetic diversity of $A$. hydrophila bacteria is very high. Several studies of the diversity of virulence factor genes in A. hydrophila were often associated with the degree of pathogenicity and toxins produced (Wang et al. 2003). The infectious pathogenicity of A. hydrophila was due to the production of several virulence factors, such as proteases, hemolysins, aerolysins, and cytolytic enterotoxins, which cause disease in fish and humans (Kingombe et al. 2010; Hu et al. 2012). The secretion of extracellular hemolysin and cytolytic enterotoxin by these bacteria is an important factor causing certain lytic activities in host cells (Watanabe et al. 2004; Uma et al. 2010). Additionally, aerolysin (aerA) is one of the virulence markers used to identify the pathogenicity of Aeromonas sp. (Zhang et al. 2013 ).

Based on the results of molecular analysis, $A$. hydrophila AHL 0905-2 and S. agalactiae N14G have been identified by virulence genes and their serotypes. Both of these bacteria are also used in the development of a combined vaccine and for ascertaining the nature of both bacteria. Also, the two isolates used together in a combination vaccine provide synergy that increases the potency of the drug to suppress the attacks of both pathogens, providing better protection.

To overcome co-infection of these bacteria, antibiotics are often used, giving rise to bacterial resistance and also influencing the environment. A more effective and safe disease control alternative is therefore needed, through developing an efficient vaccine for preventing bacterial attack by A. hydrophila and S. agalactiae in tilapia. The coinfection of these two pathogens in the culturing of tilapia in Indonesia is an important consideration in developing knowledge about the MAS and streptococcus diseases causing economic losses in tilapia aquaculture.

In conclussion, co-infection of $A$. hydrophila AHL 0905-2 and S. agalactiae N14G was confirmed as the virulent strains. Information relating to the identification of $A$. hydrophila AHL 0905-2 and $S$. agalactiae $\mathrm{N} 14 \mathrm{G}$ is important for the development of a combined vaccine as one of the ways of preventing co-infection by these pathogenic diseases in Nile tilapia.

\section{Acknowledgements}

The authors are grateful to RISPRO 2021-2022 for the research grant supporting the aims of this study. The authors are also grateful to RIFAFE, PT. Caprifarmindo laboratories, Indonesia, and to all authors who reviewed, edited, and approved the final manuscript. 


\section{References}

Al Harbi, A.H., 2016. Phenotypic and genotypic characterization of Streptococcus agalactiae isolated from hybrid tilapia(Oreochromisniloticus $\times 0$. aureus). Aquaculture. 464, 515-520. https://doi.org/10.1016/j. aquaculture.2016.07.036

Austin, B., Austin, D.A., 1993. Bacterial Fish Pathogens: Disease of Farmed and Wild Fish, second ed. Ellis Horwood, New York.

Arias, C.R., Welker, T.L., Shoemaker, C.A., Abernathy, J.W., Klesius, P.H., 2004. Genetic fingerprinting of Flavobacterium columnare isolates from cultured fish. Journal of Applied Microbiology. 97, 421-428. https://doi.org/10.1111/j.1365-2672.2004.02314.x

Aoki, T., 1999. Motile aeromonad (Aeromonas hydrophila). In: Woo P.T.K., Bruno, D.W (Eds.). Fish Diseases and Disorders Vol. 3: Viral, Bacterial and Fungal Infections. UK: CAB International. pp 427-435.

Asaad, T.M.A., 2008. Bacteriological studies on Aeromonas hydrophila in fish in Kafr El Sheikh governorate [Thesis]. Egypt: Kafr El Sheikh University.

Berkley, J.A., Crook, D.W., Seale, A.C., 2016. Capsular typing method for Streptococcus agalactiae using whole-genome sequence data. Journal of Clinical Microbiology. 54, 1388 -1390. https://doi. org/10.1128/JCM.03142-15

Bowater, R.O., Forbes-Faulkner, J., Anderson, I.G., Condon, K., Robinson, B., Kong, F., Gilbert, G.L., Reynolds, A., Hyland, S., Mcpherson, G., Brien, J.O., Blyde, D., 2012. Natural outbreak of Streptococcus agalactiae (GBS) infection in wild giant Queensland grouper, Epinepheluslanceolatus (Bloch), and other wild fish in northern Queensland, Australia. Journal of Fish Diseases. 35, 173-186. https://doi.org/10.1111/j.13652761.2011.01332.x

Carvalho-Castro, G.A., Silva, J.R., Paiva, L.V., Custódio, D.A.C., Moreira, R.O., Mian, G.F., Prado, I.A., Chalfun-Junior, A., Costa, G.M., 2017. Molecular epidemiology of Streptococcus agalactiae isolated from mastitis in Brazilian dairy herds. Brazilian Journal of Microbiology 48, 551-559. https://doi.org/10.1016/j. bjm.2017.02.004

[FAO] Food and Agriculture Organization. 2017. Global aquaculture production. Food and Agriculture Organization of the United Nations, Rome. Available at: http://www.fao.org/fishery/statistics/globalproduction/en. [Date accessed: 15 Novemper 2018]

Dong, H.T., Nguyen, V.V., Le, H.D., Sangsuriya, P., Jitrakorn, S., Saksmerprome, V., 2015. Naturally concurrent infections of bacterial and viral pathogens in disease outbreaks in cultured Nile tilapia (Oreochromis niloticus) farms. Aquaculture 448, 427-435. https:// doi.org/10.1016/j.aquaculture.2015.06.027

Dong, H.T., Siriroob, S., Meemetta, W., Santimanawong, W., Gangnonngiw, W., Pirarat, N., Khunrae, P., Rattanarojpong, T., Vanichviriyakit, R., Senapin, S., 2017. Emergence of tilapia lake virus in Thailand and an alternative semi-nested RTPCR for detection. Aquaculture 476, 111-118. https://doi.org/10.1016/j. aquaculture.2017.04.019
Eldar, A., Shapiro, O., Bejerano, Y., Bercovier, H., 1995. Vaccination with whole-cell vaccine and bacterial protein extract protects tilapia against Streptococcus difficile meningoencephalitis. Vaccine. 13, 867-870. https://doi.org/10.1016/0264-410X(94)00067-W

Garcia, J.C., Klesius, P.H., Evans, J.J., Shoemaker, C.A., 2008. Non-infectivity of cattle Streptococcus agalactiae in Nile tilapia, Oreochromis niloticus and channel catfish, Ictalurus punctatus. Aquaculture. 281, 151-154. https://doi.org/10.1016/j.aquaculture.2008.05.028

Gravekamp, C., Kasper, D.L., Paoletti, L.C., Madoff, L.C., 1999. Alpha c protein as carrier for type III capsular Polysaccharide and as a protective protein in group B streptococcal vaccines. Infection and Immunity 67, 2491-2496. https://doi.org/10.1128/IAI.67.5.24912496.1999

Hassanien, H.A., Elnady, M., Obeida, A., Itriby, H., 2004. Genetic diversity of Nile tilapia populations revealed by randomly amplified polymorphic DNA (RAPD). Aquaculture Research. 35, 587-593. https://doi. org/10.1111/j.1365-2109.2004.01057.x

Hu, M., Wang, N., Pan, Z.H., Lu, C.P., Liu, Y.J., 2012. Identity and virulence properties of Aeromonas isolates from diseased fish, healthycontrolsand waterenvironment in China. Letters in Applied Microbiology 55, 224-233. https://doi.org/10.1111/j.1472-765X.2012.03281.x

Imperi, M., Pataracchia, M., Alfarone, G., Baldassarri, L., Orefici, G., Creti, R., 2010. Multiplex PCR assay for the direct identification of the capsular type (Ia to IX) of Streptococcus agalactiae. Journal of Microbiological Methods 80, 212-214. https://doi.org/10.1016/j. mimet.2009.11.010

Iregui, C.A., Comas, J., Vasquez, G.M., Verjan, N., 2015. Experimental early pathogenesis of Streptococcus agalactiae infection in red tilapia Oreochromis spp. Journal of Fish Diseases. 39, 1-11. https://doi. org/10.1111/jfd.12347

Jones, N., Bohnsack, J.F., Takahashi, S., Oliver, K.A., Chan, M.S., Kunst, F., Glaser, P., Rusniok, C., Crook, D.W.M., Harding, R.M., Bisharat, N., Spratt, B.G., 2003. Multilocus sequence typing system for group $B$ streptococcus. Journal of Clinical Microbiology. 41, 2530 -2536. https://doi.org/10.1128/JCM.41.6.25302536.2003

Kapatai, G., Patel, D., Efstratiou, A., Chalker, V.J., 2017. Comparison of molecular serotyping approaches of Streptococcus agalactiae from genomic sequences. BMC Genomics 18, 429. https://doi.org/10.1186/ s12864-017-3820-5

Kotob, M.H., Menanteau-LeDouble, S., Kumar, G., Abdelzaher, M., El-Matbouli, M., 2016. The impact of co-infections on fish: a review. Veterinary Research. 47, 98. https://doi.org/10.1186/s13567-016-0383-4

Kingombe, C.I.B., D’Aoust, J.Y., Huys, G., Hofmann, L., Rao, M., Kwan, J., 2010. Multiplex PCR method for detection of three Aeromonas enterotoxin genes. Applied and Environmental Microbiology. 76, 425-433. https:// doi.org/10.1128/AEM.01357-09 
Lusiastuti, A.M., Seeger, H., Indrawati, A., Zschock, M., 2013. The comparison of Streptococcus agalactiae isolated from fish and bovine using multilocus sequence typing. Hayati Journal of Biosciences. 20, 157-162. https://doi.org/10.4308/hjb.20.4.157

Nam, I.Y., Joh, K., 2007. Rapid detection of virulence factors of Aeromonas isolated from a trout farm by hexaplexPCR. Journal of Microbiology. 45, 297-304.

Novita, H., Muslikha, S., Pujiayanto, S., Nurjanah., 2018. Detection of virulent genes in Aeromonas hydrophila isolated from fish samples using PCR technique. In: Proceedings of the 10th National Fish Seminar and Congress MII ke 5. Masyarakat Iktiologi Indonesia: Bogor. pp. 577-590.

Tamura, K., Peterson, D., Peterson, N., Stecher, G., Nei, M., Kumar, S., 2011. MEGA5: molecular evolutionary genetics analysis using maximum likelihood, evolutionary distance, and maximum parsimony methods. Mol. Biol. Evol. 28, 2731-2739. https://doi. org $/ 10.1093 / \mathrm{molbev} / \mathrm{msr} 121$

Uma, A., Rebecca, G., Meena, S., Saravanabava, K., 2010. PCR detection of putative aerolysin and hemolysin genes in an Aeromonas hydrophila isolate from infected Koi carp (Cyprinus carpio). Tamil Journal of Veterinary Animal Science. 6, 31-33.

Wang, G., Clark, C.G., Liu, C., Pucknell, C., Munro, C.K., Kruk, T.M., Caldeira, R., Woodward, D.L., Rodgers, F.G., 2003. Detection and characterization of the hemolysin genes in Aeromonas hydrophila and Aeromonas sobria by multiplex PCR. Journal of Clinical Microbiology 41, 1048-1054. https://doi.org/10.1128/JCM.41.3.10481054.2003
Watanabe, N., Morita, K., Furukawa, T., Manzoku, T., Endo, E., Kanamori, M., 2004. Sequence analysis of amplified DNA fragments containing the region encoding the putative lipase substrate-binding domain and genotyping of Aeromonas hydrophila. Applied Environmental Microbiology. 70, 145-151. https://doi. org/10.1128/AEM.70.1.145-151.2004

Yildirim, A.O., 2002. Pano und Genotypisierung von Stretokokken der serologischen gruppe B (Streptococcus agalactiae) isoliert von vershiedenen vertierarten [Pano and genotyping of stretococci of serological group B (Streptococcus agalactiae) isolated from different animal species] [Disertation]. Giessen, German: Fachbereich Veterinarmedizin Der Justus Liebig Universitat.

Zhang, D., Pridgeon, J.W., Klesius, P.H., 2013. Expression and activity of recombinant proaerolysin derived from Aeromonashydrophilacultured fromdiseased channel catfish. Journal of Veterinary Microbiology. 165, 478482. https://doi.org/10.1016/j.vetmic.2013.04.023 